\title{
Effects of the coexisting Baltic amphipods Monoporeia affinis and Pontoporeia femorata on the fate of a simulated spring diatom bloom
}

\author{
Wouter J. van de Bund ${ }^{1, *}$, Emil Ólafsson ${ }^{2}$, Helene Modig $^{2}$, Ragnar Elmgren $^{1}$ \\ ${ }^{1}$ Department of Systems Ecology, and ${ }^{2}$ Department of Zoology, Stockholm University, 10691 Stockholm, Sweden
}

\begin{abstract}
A laboratory experiment was performed to quantify the fate of diatom phytodetritus and how this is affected by the presence of benthic amphipods. A Baltic Sea spring bloom sedimentation event was simulated by adding ${ }^{14} \mathrm{C}$-labeled diatoms (Skeletonema costatum) to microcosms with varying densities of the amphipods Monoporeia affinis and Pontoporeia femorata, as well as to microcosms without amphipods, where the sediment was disturbed mechanically. After 1 mo of incubation, 51 to $77 \%$ of the added diatom carbon was still in the sediment; 2 mo later 49 to $66 \%$ remained. The effect of amphipods on the fate of the phytodetritus differed between species. At near-field density, M. affinis incorporated 6 to $11 \%$ of the added ${ }^{14} \mathrm{C}, P$. femorata only $1.2 \%$. The results indicate that burrowing slows mineralization, presumably by mixing organic material to anoxic depths in the sediment. The effect of $P$. femorata on mineralization could not be distinguished from the effect of mechanical stirring. M. affinis feeding and respiration resulted in a significant increase in mineralization; at low densities this compensated for the mixing effect, at high densities $M$. affinis feeding resulted in enhanced net mineralization.
\end{abstract}

KEY WORDS: Pelagic-benthic coupling $\cdot$ Amphipods $\cdot$ Deposit feeding $\cdot$ Mineralization

\section{INTRODUCTION}

The growth and population dynamics of profundal benthic organisms are often closely related to sedimentation of spring bloom phytodetritus. The importance of this form of pelagic-benthic coupling has been demonstrated in many marine, freshwater and brackish systems (Graf 1987, Rudnick 1989, Pfannkuche et al. 1992, Noji et al. 1993, Goedkoop \& Johnson 1996, Soetaert et al. 1996, Ólafsson \& Elmgren 1997, Lehtonen \& Andersin 1998). Both benthic animals (Lopez \& Levinton 1987) and bacteria (Graf 1987) can readily assimilate diatom phytodetritus at high efficiencies. One would therefore expect that organic matter would

*Present address: Netherlands Institute of Ecology, Centre for Limnology, PO Box 1299, 3600 BG Maarssen, The Netherlands. E-mail: bund@cl.nioo.knaw.nl be consumed very rapidly after sedimentation; however, there is ample evidence that this is not the case. In a comprehensive field study quantifying the fate of spring bloom diatom deposition in a eutrophic lake, Goedkoop \& Johnson (1996) estimated that bacteria, meiofauna and macrofauna together assimilated only $26 \%$ of the deposited diatom carbon, leaving $74 \%$ unaccounted for. Similarly, the results of laboratory microcosm studies using ${ }^{14} \mathrm{C}$-labelled phytodetritus show that up to $87 \%$ of the added phytodetritus remains in the sediment as particulate organic matter even after several weeks or even months incubation (Andersen \& Kristensen 1992, Kristensen et al. 1995, Andersen 1996, Gullberg et al. 1997). It has been hypothesised that degradation is slowed down by the burial of sedimented organic matter by the activity of benthic animals (van Duyl et al. 1992, van de Bund et al. 1994, Blair et al. 1996, Gullberg et al. 1997) or by 
temporary hypoxia following sedimentation events (Heiskanen \& Leppänen 1995, Kristensen et al. 1995, Andersen 1996). In contrast, a laboratory study of the loss of phytoplankton pigments from a simulated sedimentation of Baltic spring bloom material found that the presence of the amphipod Monoporeia affinis speeded up degradation (Bianchi et al. 2000).

In this paper we present a laboratory experiment demonstrating the quantitative importance of macrobenthic animals in determining the fate of a pulse of diatom phytodetritus. We compared species-specific effects of 2 Baltic amphipod species with mechanically disturbed sediments, in order to separate direct effects of the animals (feeding) from indirect effects (burial of organic matter).

The sediment and animals we used in our experiments were collected from the northern part of the Baltic Sea, where benthic communities are relatively species-poor, with only a few macrofauna species and 30 to 50 meiofauna species (Elmgren 1978, 1984, Ólafsson \& Elmgren 1997). Spring bloom phytodetritus provides a very substantial part of the annual organic matter input to these sediments (Elmgren 1978). Its fate is a key factor in the carbon budget of the Baltic Sea; it has been estimated that $32 \%$ of the estimated yearly primary production reaches the sediments (Elmgren 1984). After the brief spring diatom bloom, as much as three-quarters of its primary production may reach the sediment (Lignell et al. 1993). As a result of increasing eutrophication, large areas below the halocline of the Baltic Proper have become permanently anoxic with laminated sediments (Andersin et al. 1978). Also in shallower coastal areas benthic hypoxia frequently occurs after spring bloom sedimentation (U. Larsson pers. comm.).

In our experiments, we used the amphipods Monoporeia affinis (Lindström) and Pontoporeia femorata (Kröyer), which co-occur in the Baltic Proper, where salinity conditions are appropriate, dominating the benthic biomass and production. Many aspects of the ecology of these amphipods have been studied, including food and feeding activity (Hill \& Elmgren 1987, Lopez \& Elmgren 1989, Hill et al. 1992, Johnson \& Wiederholm 1992, Goedkoop \& Johnson 1994, Lehtonen 1994), predation (Abrams et al. 1990, Sparrevik \& Leonardsson 1995), interactions between year classes (Hill 1992), and interactions with meiobenthos (Ólafsson \& Elmgren 1991, Modig et al. 2000). M. affinis and $P$. femorata are morphologically similar, but there are important ecological differences between the 2 species. M. affinis is of freshwater origin, is very active, has a high feeding rate and accumulates lipids following spring bloom sedimentation. $P$. femorata is a marine species with a lower feeding rate and a smaller seasonal variation in its lipid reserves (Hill et al. 1992,
Lehtonen 1996). It can therefore be expected that these 2 amphipod species will respond differently to phytodetritus pulses. We expect that $M$. affinis will more effectively enhance the mineralization of spring bloom material than $P$. femorata, because of its higher feeding rate (direct effect) and more intensive mixing of the surface sediment later (indirect effect).

\section{METHODS}

Field sampling. Sediment and animals were collected in early spring 1996 from a depth of 30 to $40 \mathrm{~m}$ near the Askö field station, in the north-western Baltic Proper (58 $\left.49^{\prime} \mathrm{N}, 17^{\circ} 38^{\prime} \mathrm{E}\right)$. At this location Monoporeia affinis and Pontoporeia femorata co-occur at high densities (Elmgren 1978).

Surface sediment (ca 0 to $2 \mathrm{~cm}$ ) was collected using an epibenthic sled (Blomqvist \& Lundgren 1996) in early April, just after ice-out and several weeks before the onset of the spring diatom bloom. The sediment was sieved ( $0.5 \mathrm{~mm}$ mesh) to remove ambient macrofauna. The sediment was stored in the dark at $4{ }^{\circ} \mathrm{C}$ in an aquarium containing aerated brackish water for ca 6 wk until the start of the experiment. Amphipods Pontoporeia femorata and Monoporeia affinis were collected at the same site using an epibenthic sled and a $0.5 \mathrm{~mm}$ sieve in late April, a few days before the start of the spring bloom. Only 1-yr-old individuals of both species were used. Animals were stored in the dark at $4^{\circ} \mathrm{C}$ in aquaria with sieved sediment and aerated brackish water for ca $3 \mathrm{wk}$ before the start of the experiment.

Preparation of labelled diatoms. The diatom Skeletonema costatum Greville was cultured in artificial seawater (salinity 15\%; Kester et al. 1967), with $25 \%$ reduced $\mathrm{NaHCO}_{3}$, with added nutrients (f/2 plus $\mathrm{Si}_{\text {; }}$ Guillard 1975) at $15^{\circ} \mathrm{C}$ in $500 \mathrm{ml}$ Erlenmeyer flasks. The diatoms were labelled by adding $0.34 \mathrm{mCi}$ $\mathrm{NaH}^{14} \mathrm{CO}_{3}$ (Amersham; specific activity $54.0 \mathrm{mCi}$ $\mathrm{mmol}^{-1}$ ) to each culture flask $4 \mathrm{~d}$ after starting the culture. After 7 more days of incubation, the labelled algae were harvested in a separatory funnel. The labelled algae were washed 3 times by resuspension in clean brackish water followed by re-settling. The final radioactivity was $0.62 \mathrm{mCi} \mathrm{g}^{-1}$ diatom dry mass.

Microcosm setup (Fig. 1). Stoppered $750 \mathrm{ml}$ Erlenmeyer flasks with a bottom surface area of $78.5 \mathrm{~cm}^{2}$, completely filled with water, were used as microcosms. Each microcosm was connected to a $1500 \mathrm{ml}$ water reservoir, from which water was recirculated to the microcosms using peristaltic pumps. The residence time in the microcosms was $7.8 \mathrm{~h}$. A preliminary experiment using dyed inflowing water showed that at this pumping rate the water was mixed homoge- 


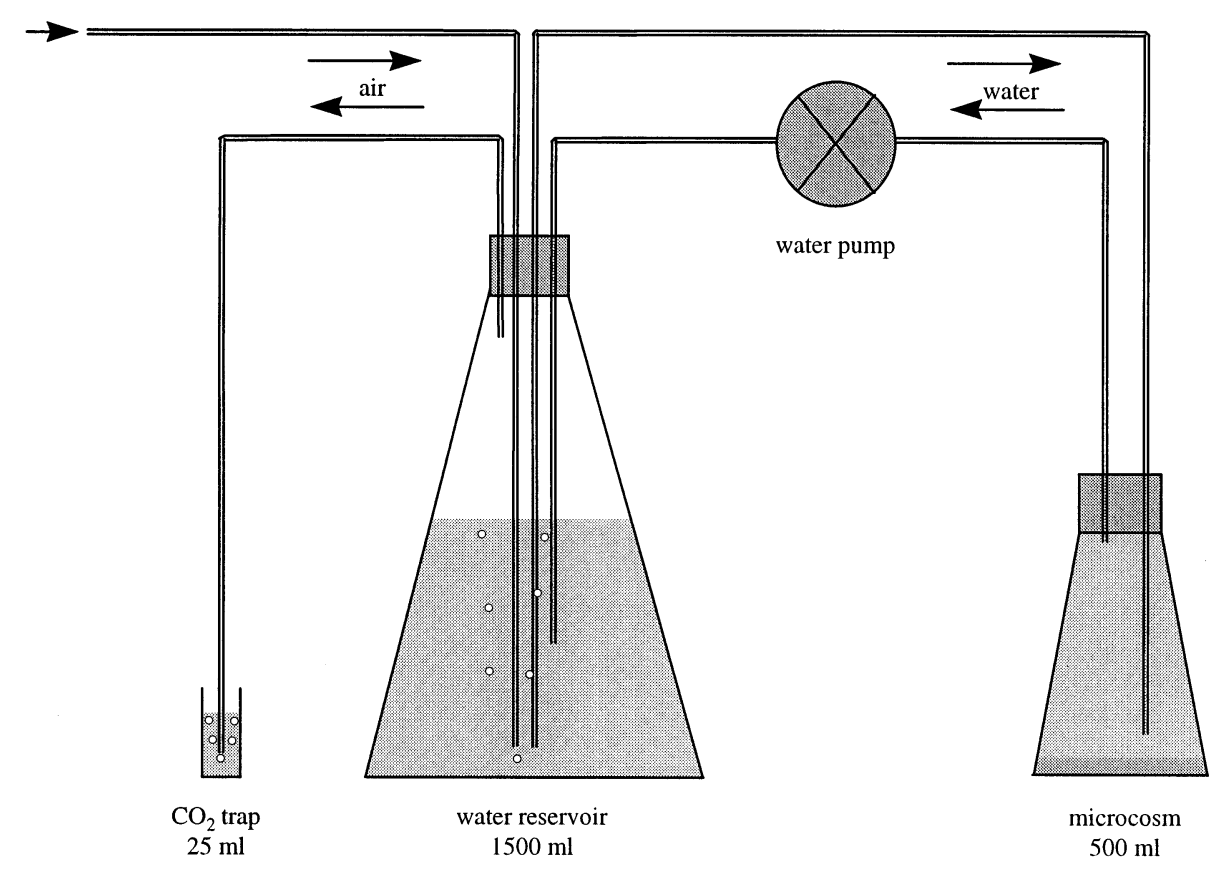

Fig. 1. Schematic of 1 of the 54 identical experimental units

neously. The water reservoirs were continuously aerated throughout the experiment; the oxygen supply to the microcosms was entirely from the inflowing aerated water, and this kept the microcosms close to saturation. Outgoing air was washed in tubes filled with $25 \mathrm{ml}$ CarboSorb E (Packard) to retain $\mathrm{CO}_{2}$.

Experimental treatments. Treatments (Table 1) included controls with sieved sediment only (S), formaldehyde-killed blinds (F), sediment with Monoporeia affinis at densities of 640, 1280 and 2560 ind. $\mathrm{m}^{-2}$ (M, M10 and M20), sediment with Pontoporeia femorata at a density of 640 ind. $\mathrm{m}^{-2}(\mathrm{P})$, sediment with both amphipods at densities of 640 ind. $\mathrm{m}^{-2}$ each (MP) and mechanically disturbed sediment without amphipods (ST). In the latter, the sediment was disturbed 3 times a week by repeated brief $(<0.5 \mathrm{~s})$ switching on of a stirring magnet (length $2.5 \mathrm{~cm}$ ), which was buried in the sediment. This resuspended the surface sediment to a few centimetres above the sediment-water interface. Amphipod densities used in the experiment were in the range typically found in the sampling area (Elmgren 1978). Microcosms were incubated at $4^{\circ} \mathrm{C}$ in the dark for $1 \mathrm{mo}$. Additional microcosms of the $\mathrm{S}$ and $\mathrm{M}$ treatments were incubated for 2 more months (SL and ML).

Originally, our experimental design consisted of 54 microcosms. However, during the first days of the experiment 1 of the 4 peristaltic pumps broke down, resulting in temporary hypoxia and consequent amphipod mortality in 15 microcosms. The reported results are from the 39 unaffected microcosms only; as a result, the division of replicates over the treatments is

Table 1. Monoporeia affinis and Pontoporeia femorata. Overview of experimental treatments. Numbers of replicates as used in data analysis; treatments M10 and M20 were pooled into $\mathrm{MH}$ (see text)

\begin{tabular}{|c|c|c|c|}
\hline & \multirow[t]{2}{*}{ Treatment } & \multicolumn{2}{|c|}{ No. of replicates } \\
\hline & & 1 mo incubation & 3 mo incubation \\
\hline Sieved sediment & $\mathrm{S}, \mathrm{SL}$ & $5(\mathrm{~S})$ & $4(\mathrm{SL})$ \\
\hline M. affinis: 5 ind. microcosm ${ }^{-1}$ & M, ML & $6(\mathrm{M})$ & 4 (ML) \\
\hline M. affinis: 10 ind. microcosm ${ }^{-1}$ & $\mathrm{M} 10 \rightarrow \mathrm{MH}$ & 2 & - \\
\hline M. affinis: 20 ind. microcosm ${ }^{-1}$ & $\mathrm{M} 20 \rightarrow \mathrm{MH}$ & 2 & - \\
\hline P. femorata: 5 ind. microcosm ${ }^{-1}$ & $\mathrm{P}$ & 4 & - \\
\hline$M$. affinis $+P$. femorata: $5+5$ ind. microcosm $^{-1}$ & MP & 6 & - \\
\hline Disturbed sieved sediment & $\mathrm{ST}$ & 4 & - \\
\hline Formaldehyde-killed sieved blinds & $\mathrm{F}$ & 2 & - \\
\hline
\end{tabular}


unbalanced (Table 1). The 2 treatments with high Monoporeia affinis densities (M10 and M20) were particularly affected. Since their results were quite similar, these 2 were pooled into 1 treatment $(\mathrm{MH})$ for statistical analysis to ensure sufficient replicates.

Start of the experiment. The microcosms were incubated in the dark at a constant temperature of $4{ }^{\circ} \mathrm{C}$. Three weeks before addition of labelled algae, $75 \mathrm{~g}$ sediment (wet mass) was added to each microcosm, forming a layer of ca $1.5 \mathrm{~cm}$. Microcosms and water reservoirs were filled with brackish seawater (salinity $7 \%$ ) and the sediment was allowed to settle for $24 \mathrm{~h}$ before the pumps were switched on. Four days later amphipods were added, and stirring of the sediment in the ST treatment started. In the blinds $(\mathrm{F})$, formaldehyde was added to the water reservoirs $2 \mathrm{~d}$ before addition of labelled diatoms, to a final concentration of $4 \%$.

Using a Pasteur pipette, $3 \mathrm{ml}$ of diatom suspension containing $28.8 \mathrm{mg}$ diatom dry mass with a total activity of $2.8 \times 10^{7}$ DPM was added to each microcosm, evenly distributing the algae over the sediment surface. The added diatom biomass ( $3.7 \mathrm{~g}$ dry mass $\mathrm{m}^{-2}$ ) corresponds to a few days of sedimentation during a typical spring bloom in the field (Blomqvist \& Larsson 1994). The $\mathrm{CO}_{2}$ traps were connected immediately after addition of the diatoms.

Community respiration measurements. Radioactivity in the $\mathrm{CO}_{2}$ traps was measured after 7, 9, 23 and $29 \mathrm{~d}$ (all microcosms), as well as after 2 and 3 mo (SL and ML treatments) by taking a $1 \mathrm{ml}$ subsample from the traps, adding $10 \mathrm{ml}$ scintillation liquid (PermaFluor E+, Packard), and counting in a liquid scintillation counter (see below). The $\mathrm{CO}_{2}$ traps were replaced after each sampling. At the same instances, two $1 \mathrm{ml}$ water samples were taken from each water reservoir. To 1 of these samples $1 \mathrm{ml}$ CarboSorb was added to fix $\mathrm{CO}_{2}$, to the other $1 \mathrm{ml} 1 \mathrm{~N} \mathrm{HCl}$ was added to release $\mathrm{CO}_{2}$. Water samples were counted in $10 \mathrm{ml}$ Hionic-Fluor (Packard). Dissolved ${ }^{14} \mathrm{CO}_{2}$ in the water was calculated from the activity in samples with fixed and released $\mathrm{CO}_{2}$. Total released ${ }^{14} \mathrm{CO}_{2}$ was calculated from activity in the traps and dissolved ${ }^{14} \mathrm{CO}_{2}$.

End of the experiment. When the experiment was terminated after 1 or $3 \mathrm{mo}$, the water was carefully removed from the microcosms; the sediment was sieved using a $0.5 \mathrm{~mm}$ mesh; and dead and live animals were counted, rinsed in distilled water, and frozen individually in $1 \mathrm{ml}$ Eppendorf vials. Sediment radioactivity was measured by solubilizing a freezedried sample of the homogenised sediment overnight at $50^{\circ} \mathrm{C}$ in $80 \%$ Soluene-350 (Packard), adding $10 \mathrm{ml}$ Hionic-Fluor (Packard) and counting using a liquid scintillation counter (see below). Amphipods were freeze-dried and individually weighed on an elec- trobalance. To measure radioactivity in individual amphipods, they were solubilized overnight at $50^{\circ} \mathrm{C}$ in $80 \%$ Soluene-350 (Packard); $5 \mathrm{ml}$ Hionic-Fluor (Packard) was added to each sample. All radioactivity samples were counted with a LKB scintillation counter using a standard ${ }^{14} \mathrm{C}$ counting program.

We checked the variability of replicate samples within individual microcosms for all radioactivity measurements (sediment, water, $\mathrm{CO}_{2}$ traps and animals) before performing the experiment; this variability was always below ca $10 \%$, in most cases considerably lower. For practical reasons we therefore analysed unreplicated samples.

Data analysis. To reduce variation caused by differences in the amount of radioactivity added to each microcosm, the radioactivity measured as ${ }^{14} \mathrm{CO}_{2}$, amphipod ${ }^{14} \mathrm{C}$, DO ${ }^{14} \mathrm{C}$ and sediment ${ }^{14} \mathrm{C}$ in each microcosm was expressed as a fraction of the total radioactivity measured in that microcosm. To minimize handling of radioactive material, the algae were added in a small volume from a highly concentrated suspension. The reported statistical analyses are based on these fractionated data.

Data were transformed using the arcsine (percentage data) or $\log _{10}$ (other data) transformations; homogeneity of the variances was checked using Cochran's $C$-test. Data were analysed using analysis of variance (ANOVA) and Tukey's test for unequal sample size for a posteriori comparison of means.

\section{RESULTS}

\section{Budget for recovered ${ }^{14} \mathrm{C}$}

On average, $80 \%$ of the added diatom ${ }^{14} \mathrm{C}$ was recovered in the measured fractions (sediment ${ }^{14} \mathrm{C}$, ${ }^{14} \mathrm{CO}_{2}, \mathrm{DO}{ }^{14} \mathrm{C}$ and amphipod ${ }^{14} \mathrm{C}_{i}$ Table $\left.2 \mathrm{a}, \mathrm{b}\right)$. There was no significant treatment effect (1-way ANOVA, $p=0.19$ ) on total recovery of added radioactivity for either incubation period.

In the 2 formalin blinds the average recovery of the added radioactivity was $83 \%$. Of the recovered material in the blinds, $1.5 \%$ was measured as ${ }^{14} \mathrm{CO}_{2}, 6.5 \%$ as $\mathrm{DO}^{14} \mathrm{C}$, and the remaining $92.0 \%$ as sediment ${ }^{14} \mathrm{C}$.

After $1 \mathrm{mo}, 51$ to $77 \%$ of the recovered radioactivity was measured as sediment ${ }^{14} \mathrm{C}$ (Table 2a). There was a significant treatment effect (1-way ANOVA, p < 0.002); sediment radioactivity was lower in the treatment with Monoporeia affinis at high density $(\mathrm{MH})$ than in all other treatments $(\mathrm{p}<0.05)$, while differences between the other treatments were not significant $(p>0.05)$. Radioactivity in the ${ }^{14} \mathrm{CO}_{2}$ and $\mathrm{DO}^{14} \mathrm{C}$ fractions did not differ between treatments (1-way ANOVA, $p>0.05$ ). The amount of radioactivity accumulated in amphipod bio- 
Table 2. Monoporeia affinis and Pontoporeia femorata. ${ }^{14} \mathrm{C}$ budget of microcosms after (a) 1 mo and (b) 3 mo incubation with labeled phytodetritus; standard errors in parentheses. Letter codes show homogeneous groups (Tukey test for unequal $\mathrm{n}$, $\mathrm{p}<$ 0.05) between treatments. (c) Effect of presence/absence of Monoporeia affinis and incubation time on the ${ }^{14} \mathrm{C}$ budget of microcosms with labeled phytodetritus; analysis by 2-way ANOVA. ns: not significant; ${ }^{*} \mathrm{p}<0.05{ }^{* * *} \mathrm{p}<0.01{ }^{* * *} \mathrm{p}<0.001$

\begin{tabular}{|c|c|c|c|c|c|c|}
\hline \multicolumn{7}{|c|}{ (a) ${ }^{14} \mathrm{C}$ budget after $1 \mathrm{mo}$} \\
\hline \multirow{2}{*}{ Treatment } & \multirow{2}{*}{$\begin{array}{l}\text { Total measured }{ }^{14} \mathrm{C}\left(10^{7} \mathrm{dpm}\right) \\
\qquad=100 \%)\end{array}$} & \multicolumn{5}{|c|}{$\%$ of total measured ${ }^{14} \mathrm{C}$} \\
\hline & & ${ }^{14} \mathrm{CO}_{2}$ & $\mathrm{DO}^{14} \mathrm{C}$ & M. affinis & P. femorata & Sediment \\
\hline $\mathrm{S}$ & $2.2(0.2)$ & $29(8)$ & $8(4)$ & - & - & $63(9) \mathrm{b}$ \\
\hline M & $2.2(0.3)$ & $24(7)$ & $5(2)$ & $6(3) \mathrm{a}$ & - & $65(10) \mathrm{b}$ \\
\hline MH & $2.5(0.1)$ & $31(8)$ & $7(0)$ & $11(2) b$ & - & 51 (9)a \\
\hline $\mathrm{P}$ & $2.1(0.2)$ & $16(5)$ & $5(1)$ & - & $1.2(0.2) \mathrm{a}$ & $77(5) b$ \\
\hline MP & $2.2(0.3)$ & $23(4)$ & $6(1)$ & 4 (1)a & $0.2(0.1) \mathrm{b}$ & $67(5) b$ \\
\hline ST & $2.0(0.3)$ & $19(10)$ & $5(1)$ & - & - & $77(10) \mathrm{b}$ \\
\hline \multirow[t]{2}{*}{ ANOVA results } & 5,23 & 5,23 & 5,23 & 2,13 & 1,8 & 5,23 \\
\hline & $0.14 \mathrm{~ns}$ & $0.07 \mathrm{~ns}$ & $0.36 \mathrm{~ns}$ & $0.001^{* *}$ & $0.000^{* * *}$ & $0.002^{* *}$ \\
\hline \multicolumn{7}{|c|}{ (b) ${ }^{14} \mathrm{C}$ budget after $3 \mathrm{mo}$} \\
\hline \multirow{2}{*}{ Treatment } & \multirow{2}{*}{ Total measured ${ }^{14} \mathrm{C}\left(10^{7} \mathrm{dpm}\right)$} & \multicolumn{4}{|c|}{$\%$ of total measured ${ }^{14} \mathrm{C}$} & \\
\hline & & ${ }^{14} \mathrm{CO}_{2}$ & $\mathrm{DO}^{14} \mathrm{C}$ & M. affinis & Sediment & \\
\hline SL & $2.2(0.4)$ & $30(5)$ & $5(4)$ & - & $66(8)$ & \\
\hline ML & $2.0(0.2)$ & $41(9)$ & $7(1)$ & $3(2)$ & $49(7)$ & \\
\hline \multicolumn{7}{|c|}{ (c) Effect of $M$. affinis and incubation time } \\
\hline & ${ }^{\text {Total measured }}$ & $\begin{array}{l}{ }^{\%}{ }^{14} \mathrm{C} \text { as } \\
{ }^{14} \mathrm{CO}_{2}\end{array}$ & $\begin{array}{l}{ }^{\%}{ }^{14} \mathrm{C} \text { in } \\
\mathrm{DO}^{14} \mathrm{C}\end{array}$ & $\begin{array}{l}\%{ }^{14} \mathrm{C} \text { in } \\
\text { M. affinis }\end{array}$ & $\begin{array}{l}\%{ }^{14} \mathrm{C} \text { in } \\
\text { sediment }\end{array}$ & \\
\hline & 1,15 & 1,15 & 1,15 & 1,8 & 1,15 & \\
\hline (1) M. affinis & $0.43 \mathrm{~ns}$ & $0.72 \mathrm{~ns}$ & $0.83 \mathrm{~ns}$ & - & $0.07 \mathrm{~ns}$ & \\
\hline (2) Incubation & $0.48 \mathrm{~ns}$ & $0.03^{*}$ & $0.55 \mathrm{~ns}$ & $0.21 \mathrm{~ns}$ & $0.08 \mathrm{~ns}$ & \\
\hline Interaction $1 \times 2$ & $0.42 \mathrm{~ns}$ & $0.07 \mathrm{~ns}$ & $0.09 \mathrm{~ns}$ & - & $0.03^{*}$ & \\
\hline
\end{tabular}

mass ranged from 1 to $11 \%$. M. affinis incorporated 4 to $11 \%$ of total measured ${ }^{14} \mathrm{C}$, with significant differences between the 3 treatments where it was present (1-way ANOVA, $p<0.001)$. More label was incorporated in $M$. affinis at high density (MH) than at low density in presence (MP) and absence (M) of Pontoporeia femorata ( $p<0.01)$. The presence of $P$. femorata had no significant effect on $M$. affinis label uptake ( $p>0.05$ ).

Much less radioactivity was measured in Pontoporeia femorata than in Monoporeia affinis (Table 2a). When incubated alone (P), P. femorata incorporated $1.2 \%$ of the total measured ${ }^{14} \mathrm{C}_{i}$ in presence of $M$. affinis (MP) incorporation was only $0.2 \%$. This difference was highly significant ( $t$-test, $\mathrm{p}<0.001$ ) and is the combined effect of an increased mortality (see Fig. 2) and a decrease in the radioactivity per individual amphipod (see Fig. 4).

After $3 \mathrm{mo}$, the recovery of the added radioactivity (Table 2b) was about the same as after 1 mo. A 2-way ANOVA with presence/absence of Monoporeia affinis and incubation time as independent variables was used to analyse the data from the treatments S, SL, M and ML (Table 2c). Effects on total measured ${ }^{14} \mathrm{C}$, $\mathrm{DO}^{14} \mathrm{C}$ and ${ }^{14} \mathrm{C}$ in $M$ affinis were not significant. Total released ${ }^{14} \mathrm{CO}_{2}$ was significantly higher after 3 mo than after $1 \mathrm{mo}(\mathrm{p}<0.05)$. There was a significant interaction effect $(p<0.05)$ between incubation time and the presence of $M$. affinis on ${ }^{14} \mathrm{C}$ remaining in the sediment. In the treatments with added $M$. affinis, less ${ }^{14} \mathrm{C}$ remained in the sediment after 3 mo than after 1 mo, while without amphipods similar amounts were measured in both cases.

\section{${ }^{14} \mathrm{C}$ in $\mathrm{CO}_{2}$ traps}

Table 3a summarises the rates of ${ }^{14} \mathrm{CO}_{2}$ release during the experiment. The data for the periods $0-7,7-9$, 9-23 and 23-29 d were analysed using a 2-way repeated-measures ANOVA (Table 3b); significant effects were found for treatment $(p<0.05)$, incubation time $(\mathrm{p}<0.0001)$ and the interaction between these factors $(\mathrm{p}<0.001)$. The rate of ${ }^{14} \mathrm{CO}_{2}$ release decreased significantly over time (Table $3 a)$. 
Table 3. Monoporeia affinis and Pontoporeia femorata. (a) ${ }^{14} \mathrm{CO}_{2}$ production (\% of total measured ${ }^{14} \mathrm{Cd}^{-1}$ ) in microcosms with labeled phytodetritus throughout the experiment; standard errors in parentheses. (b) Effect of treatment and incubation time on ${ }^{14} \mathrm{CO}_{2}$ production rates (2-way repeated-measures ANOVA, $t=7,9,23$ and $\left.29 \mathrm{~d}\right) .{ }^{*} \mathrm{p}<0.05 ;^{* *} \mathrm{p}<0.01 ;{ }^{* * *} \mathrm{p}<0.001$

\begin{tabular}{|c|c|c|c|c|c|c|}
\hline \multicolumn{3}{|l|}{$\begin{array}{l}\text { (a) }{ }^{14} \mathrm{CO}_{2} \text { production } \\
\text { Treatment }\end{array}$} & \multicolumn{2}{|c|}{${ }^{14} \mathrm{CO}_{2}$ production rates } & \multirow[b]{2}{*}{$t=59$} & \multirow[b]{2}{*}{$t=95$} \\
\hline & $t=7$ & $t=9$ & $t=23$ & $t=29$ & & \\
\hline $\mathrm{S}$ & $1.0(0.5)$ & $0.5(0.2)$ & $1.1(0.4)$ & $0.9(0.2)$ & $0.3(0.2)$ & $0.0(0.0)$ \\
\hline M & $1.1(0.3)$ & $0.8(0.2)$ & $0.8(0.23)$ & $0.5(0.3)$ & $0.6(0.4)$ & $-0.0(0.1)$ \\
\hline MH & $1.6(0.3)$ & $1.2(0.2)$ & $1.1(0.4)$ & $0.5(0.3)$ & - & - \\
\hline $\mathrm{P}$ & $1.0(0.8)$ & $0.4(0.2)$ & $0.4(0.4)$ & $0.1(0.2)$ & - & - \\
\hline MP & $1.2(0.3)$ & $1.0(0.3)$ & $0.8(0.2)$ & $0.4(0.2)$ & - & - \\
\hline ST & $0.5(0.2)$ & $0.6(0.4)$ & $0.9(0.5)$ & $0.3(0.4)$ & - & - \\
\hline \multicolumn{7}{|c|}{ (b) Effect of treatment and incubation time } \\
\hline Effect & df & $\mathrm{p}$ & & & & \\
\hline (1) Treatment & 5,23 & $0.03^{*}$ & & & & \\
\hline (2) Incubation time & 3,69 & $0.000^{* * *}$ & & & & \\
\hline Interaction $1 \times 2$ & 15,69 & $0.001^{* *}$ & & & & \\
\hline
\end{tabular}

\section{Effects on amphipods}

There was a significant treatment effect on amphipod mortality after 1 mo of incubation (Fig. 2; 1-way ANOVA, $\mathrm{p}<0.001$ ). Monoporeia affinis mortality was always less than $10 \%$, without significant differences among treatments $(\mathrm{p}>0.05)$. Pontoporeia femorata mortality was $15 \%$ when incubated alone, but $57 \%$ when incubated together with $M$. affinis; the latter value was significantly higher than all other mortalities $(\mathrm{p}<0.05)$. Observations of the appearance of dead amphipods on the sediment surface showed that mortality occurred almost exclusively during the first week of the experiment, just after addition of the diatoms to the microcosms.

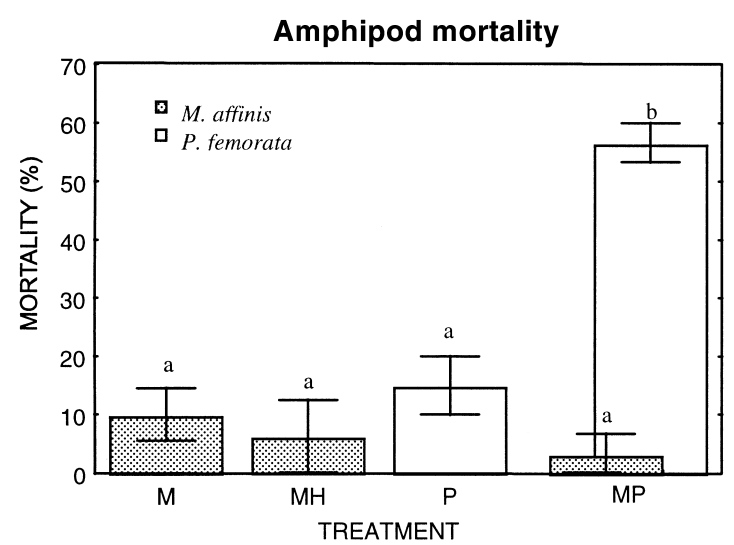

Fig. 2. Monoporeia affinis and Pontoporeia femorata. Amphipod mortality after 1 mo of incubation. Letter codes show significant differences (Tukey test for unequal $n, p<0.05$ ) between treatments
Individual amphipod biomasses (Fig. 3) differed significantly between species (1-way ANOVA, p < 0.05), with Pontoporeia femorata being heavier than Monoporeia affinis $(\mathrm{p}<0.05)$. There was no significant treatment effect on biomass for either species ( $p>0.05$ ). Intra- and interspecific differences were found for the amount of radioactivity measured per individual amphipod (Fig. 4; 1-way ANOVA, p < 0.001). P. femorata incorporated consistently less than $M$. affinis $(\mathrm{p}<$ 0.01). When incubated alone, $P$. femorata incorporated more ${ }^{14} \mathrm{C}$ than when incubated with $M$. affinis $(\mathrm{p}<$ 0.05).

Monoporeia affinis mortality after 3 mo incubation (Table 4) was higher than after 1 mo (Mann-Whitney $U$-test, $\mathrm{p}<0.001$; a non-parametric test was used be-

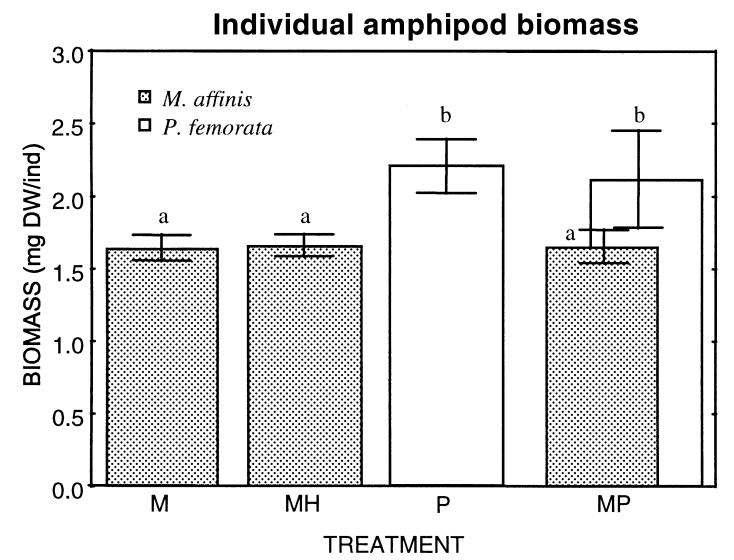

Fig. 3. Monoporeia affinis and Pontoporeia femorata. Amphipod individual biomass after 1 mo of incubation. Letter codes show significant differences (Tukey test for unequal n, $\mathrm{p}<0.05$ ) between treatments 


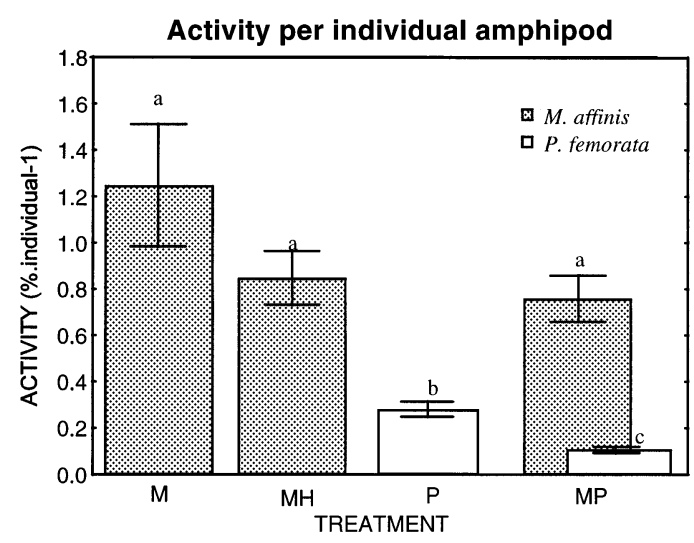

Fig. 4. Monoporeia affinis and Pontoporeia femorata. Incorporated ${ }^{14} \mathrm{C}$ in amphipods after 1 mo incubation (as percentage of total recovered ${ }^{14} \mathrm{C}$ ). Letter codes show homogeneous groups (Tukey test for unequal $n, p<0.05$ )

cause the variance in 1 of the treatments was 0 ). There were no significant differences in individual $M$. affinis dry mass and radioactivity per individual ( $t$-test, $\mathrm{p}>$ 0.05) between incubation times.

\section{DISCUSSION}

Slightly over $80 \%$ of the radioactivity added in the experiment could be accounted for; this was the case for all treatments, including the formalin blinds. Where the remaining near $20 \%$ went is not clear; possibly it was absorbed to the walls of the microcosms, water reservoirs and/or tubing. Another possibility is that part of the radioactivity was washed out of the microcosms as particulate material and sedimented in the water reservoirs.

From the carbon budgets it is clear that most of the added phytodetritus was neither released as ${ }^{14} \mathrm{CO}_{2}$ nor taken up by amphipods during the 3 mo experiment, but remained in the sediment. This result is in agreement with many laboratory studies with a variety of experimental setups (Andersen \& Kristensen 1992, Hansen \& Blackburn 1992, Fitzgerald \& Gardner 1993, Webb \& Montagna 1993, Andersen 1996, Gullberg et al. 1997, Ólafsson et al. 1999). It is likely that most of this material is utilised on longer time scales. Graf (1987) found that after addition of fresh phytodetritus most of the heat production in the sediment was from old organic material already present in the sediment. In a mesocosm experiment, Rudnick (1989) showed that there are 2 distinct meiofauna groups utilising fresh and old detrital food sources, respectively; Ólafsson \& Elmgren (1997) came to the same conclusion from a field study quantifying seasonal dynamics of the meiofauna in the Baltic Sea. The mineralization of the more refractory organic material occurs probably on a time scale much longer than the duration of the average microcosm experiment, years rather than months. In contrast, compounds that are relatively easily degraded, such as chlorophyll $a$ in spring bloom material, can be totally broken down in less than 2 mo in the presence of the amphipod Monoporeia affinis under conditions similar to those of our study (Bianchi et al 2000).

Stirring, resulting in the burial of diatom material, appears to inhibit phytodetritus mineralization, while the feeding activity of Monoporeia affinis seems to enhance it. At low M. affinis densities, these inhibiting and enhancing effects appear more or less balanced, while at higher densities the enhancement of mineralization by $M$. affinis feeding is more important, as also found by Bianchi et al. (2000). The effect of Pontoporeia femorata on carbon mineralization in our experiment appears to be mostly abiotic: a burial of freshly sedimented material resulting in slower mineralization.

Monoporeia affinis took up more of the labelled phytodetritus than Pontoporeia femorata. The smaller size of $M$. affinis would tend to increase its relative metabolic rate, but the difference in uptake in radioactive material was far greater than can be explained by the small difference in mean mass between the 2 species. This difference is consistent with the higher feeding (Lopez \& Elmgren 1989) and respiration rates (Cederwall 1979, Lehtonen 1995) of $M$. affinis, and with its more opportunistic utilisation of available food resources, as reflected by seasonal patterns of lipid storage related to sedimentation events in the field

Table 4. Monoporeia affinis. Mortality, individual dry mass, and radioactivity per individual after 1 and 3 mo incubation with labeled phytodetritus (treatments M and ML) with test results; standard errors in parentheses. ns: not significant; ${ }^{* * *}$ p $<0.001$

\begin{tabular}{|lcccc|}
\hline Treatment & $\begin{array}{c}\text { Incubation } \\
(\mathrm{mo})\end{array}$ & $\begin{array}{c}\text { Mortality } \\
(\%)\end{array}$ & $\begin{array}{c}\text { Biomass } \\
\left.\text { (mg dw ind } \cdot^{-1}\right)\end{array}$ & $\begin{array}{c}{ }^{14} \mathrm{C} \\
\left(\% \text { of total ind } .^{-1}\right)\end{array}$ \\
\hline $\mathrm{M}$ & 1 & $10(1.8)$ & $1.6(0.04)$ & $1.2(0.11)$ \\
ML & 3 & $20(0.0)$ & $1.4(0.06)$ & $0.8(0.14)$ \\
$t$-test $p$ & & - & $0.20 \mathrm{~ns}$ & $0.15 \mathrm{~ns}$ \\
Mann-Whitney test $\mathrm{p}$ & & $0.000^{* * *}$ & - & - \\
\hline
\end{tabular}


(Hill et al. 1992, Lehtonen 1996). Most individuals of both species had full guts upon termination of the experiment, indicating that they were feeding. When incubated alone at equal density, $M$. affinis incorporated almost 5 -fold more label than $P$. femorata. This is in good agreement with reported differences in feeding rates between the 2 species; Lopez \& Elmgren (1989) estimated that $P$. femorata and $M$. affinis have gut turnover times of ca 2.6 and $0.9 \mathrm{~h}$, respectively. The gut volume of $M$. affinis of a size similar to those used in our experiment was estimated to be $0.25 \mathrm{~mm}^{3}$ (Elmgren et al. 1986). If we assume the gut volume of $P$. femorata is the same, and that both species feed exclusively from the top centimetre of the sediment, each amphipod could in 1 mo only have ingested $0.08 \%$ (P. femorata) and $0.25 \%$ (M. affinis) of the sediment available to them in our $78.5 \mathrm{~cm}^{2}$ microcosms. If feeding would be non-selective with an assimilation efficiency of $40 \%$ (Lopez \& Elmgren 1989), and the labelled food was uniformly mixed into the sediment, the $5 \mathrm{P}$. femorata could have taken up maximally $0.15 \%$ and the $20 \mathrm{M}$. affinis maximally $2 \%$ of the added radioactivity. However, their maximum label uptake was over 5 times higher (Fig. 4), indicating that 1 or more of the assumptions were not valid. Initially, the added phytodetritus was clearly not uniformly mixed into the sediment, allowing the amphipods to feed selectively on a thin surface layer of high food quality, for which assimilation efficiency may be higher than $40 \%$. Our finding that label uptake by $P$. femorata was significantly reduced in sympatry with M. affinis (Fig. 4) may be the result of interactive spatial niche segregation of the 2 species, as mentioned above. This may have caused $P$. femorata to burrow deeper into the sediment, from where it had little access to the high-quality food at the sediment surface.

The high Pontoporeia femorata mortality in the presence of Monoporeia affinis during the first days of the experiment may have been caused by unfavourable oxygen conditions and/or sulphide toxicity. Following sedimentation events, brief periods of oxygen deficiency and increased sulphate reduction rates in surface sediments have been demonstrated (Graf 1987, Hansen \& Blackburn 1992, Moeslund et al. 1994). Oxygen penetration following addition of diatom phytodetritus in a similar experiment with the same microcosm setup as the one used in our experiment was not more than $2 \mathrm{~mm}$, even though the oxygen concentration remained high in the overlying water (W.J.v.d.B. unpubl. results). The observed difference in mortality between $M$. affinis and $P$. femorata is consistent with the known behavioural and physiological differences between these species. In sympatry $M$. affinis and $P$. femorata segregate spatially, with the latter species burrowing deeper into the sediment (Hill \& Elmgren
1987), thereby exposing itself to more unfavourable oxygen conditions. Furthermore, P. femorata is more sensitive to oxygen stress than $M$. affinis (Johansson 1997). $M$. affinis thus appears to be better equipped to deal with brief periods of oxygen deficiency than $P$. femorata. In the restricted sediment depth of our experiments, $P$. femorata was not able to fully escape interactions with $M$. affinis by burrowing, which may have caused intense escape activity that interacted with oxygen stress to increase mortality.

The results of these microcosm experiments cannot be directly extrapolated to the field situation. Our 'phytodetritus' input consisted of fresh material from 1 species of diatoms, the sediment depth in the microcosms was less than $2 \mathrm{~cm}$, and the experimental setup eliminates lateral transport and reduces resuspension of sediment, 2 processes likely to be very important in the field (Blomqvist \& Larsson 1994). However, the results presented clearly demonstrate the close relation between phytodetritus sedimentation events, macroinvertebrate feeding and mixing activity.

Acknowledgements. Many thanks to Nils Walberg for building the microcosm setup, to Jan-Erik Hägerroth for assistance in the field, and to Lars-Åke Gisselsson for providing the algae. Willem Goedkoop and Lars Byrén gave helpful comments on the manuscript. This research was supported by a Marie Curie postdoctoral fellowship to W.J.v.d.B. and NFR grants to R.E.

\section{LITERATURE CITED}

Abrams PA, Hill C, Elmgren R (1990) The functional response of the predatory polychaete, Harmothoe sarsi, to the amphipod, Pontoporeia affinis. Oikos 59:261-269

Andersen FØ (1996) Fate of organic carbon added as diatom cells to oxic and anoxic marine sediment microcosms. Mar Ecol Prog Ser 134:1-3

Andersen FØ, Kristensen E (1992) The importance of benthic macrofauna in decomposition of microalgae in a coastal marine sediment. Limnol Oceanogr 37:1392-1403

Andersin AB, Lassing J, Parkkonen L, Sandler H (1978) The decline of macrofauna in the deeper parts of the Baltic proper and the Gulf of Finland. Kiel Meeresforsch Sonderb 4:23-52

Bianchi TS, Johansson B, Elmgren R (2000) The effects of anoxia and loss of deposit-feeding macrofauna on phytoplankton pigment breakdown in Baltic sediments. J Exp Mar Biol Ecol 251:161-183

Blair NE, Levin LA, DeMaster DJ, Plaia G (1996) The shortterm fate of fresh algal carbon in continental slope sediments. Limnol Oceanogr 41:1208-1219

Blomqvist S, Larsson U (1994) Detrital bedrock elements as tracers of settling resuspended particulate matter in a coastal area of the Baltic Sea. Limnol Oceanogr 39:880-896

Blomqvist S, Lundgren L (1996) A benthic sled for sampling soft bottoms. Helgol Meeresunters 50:453-456

Cederwall H (1979) Diurnal oxygen consumption and activity of two Pontoporeia (Amphipoda, Crustacea) species. In: Naylor E, Hartnoll RG (eds) Cyclic pheonomena in marine plants and animals. Pergamon Press, Oxford, p 309-316

Elmgren R (1978) Structure and dynamics of Baltic benthos 
communities, with particular reference to the relationship between macro- and meiofauna. Kiel Meeresforsch Sonderh $4: 1-22$

Elmgren R (1984) Trophic dynamics in the enclosed, brackish Baltic Sea. Rapp PV Réun Cons Int Explor Mer 183: 152-169

Elmgren R, Ankar S, Marteleur B, Ejdung G (1986) Adult interference with postlarvae in soft sediments: the Pontoporeia-Macoma example. Ecology 67:827-836

Fitzgerald SA, Gardner WS (1993) An algal carbon budget for pelagic-benthic coupling in Lake Michigan. Limnol Oceanogr 38:547-560

Goedkoop W, Johnson RK (1994) Exploitation of sediment bacterial carbon by juveniles of the amphipod Monoporeia affinis. Freshw Biol 32:553-563

Goedkoop W, Johnson RK (1996) Pelagic-benthic coupling: profundal benthic community response to spring diatom deposition in mesotrophic Lake Erken. Limnol Oceanogr 41:636-647

Graf G (1987) Benthic energy flow during a simulated autumn bloom sedimentation. Mar Ecol Prog Ser 39:23-29

Guillard RL (1975) Culture of phytoplankton for feeding marine invertebrates. In: Smith WL, Chanley MH (eds) Culture of marine invertebrate animals. Plenum Press, New York, p 29-60

Gullberg KR, Goedkoop W, Johnson RK (1997) The fate of diatom carbon within a freshwater benthic community-a microcosm study. Limnol Oceanogr 42:452-460

Hansen LS, Blackburn TH (1992) Effect of algal bloom deposition on sediment respiration and fluxes. Mar Biol 116: 147-152

Heiskanen AS, Leppänen JM (1995) Estimation of export production in the coastal Baltic Sea: effect of resuspension and microbial decomposition on sedimentation measurements. Hydrobiologia 316:211-224

Hill C (1992) Interactions between year classes in the benthic amphipod Monoporeia affinis: effects on juvenile survival and growth. Oecologia 91:157-162

Hill C, Elmgren R (1987) Vertical distribution in the sediment in the co-occurring benthic amphipods Pontoporeia affinis and P. femorata. Oikos 49:221-229

Hill C, Quigley MA, Cavaletto JF, Gordon W (1992) Seasonal changes in lipid content and composition in the benthic amphipods Monoporeia affinis and Pontoporeia femorata. Limnol Oceanogr 37:1280-1289

Johansson B (1997) Tolerance of the deposit-feeding Baltic amphipods Monoporeia affinis and Pontoporeia femorata to oxygen deficiency. Mar Ecol Prog Ser 151:135-141

Johnson RK, Wiederholm $\mathrm{T}$ (1992) Pelagic-benthic coupling - the importance of diatom interannual variability for population oscillations of Monoporeia affinis. Limnol Oceanogr 37:1596-1607

Kester DR, Duedall IW, Connors DN, Pytkovocz RM (1967) Preparation of artificial seawater. Limnol Oceanogr 12:176-179

Kristensen E, Ahmed SI, Devol AH (1995) Aerobic and anaerobic decomposition of organic matter in marine sediment: which is fastest? Limnol Oceanogr 40:1430-1437

Lehtonen KK (1994) Metabolic effects of short-term starvation on the benthic amphipod Pontoporeia affinis Lindstroem from the northern Baltic Sea. J Exp Mar Biol Ecol 176: 269-283

Lehtonen KK (1995) Geographical variability in the bioenergetic characteristics of Monoporeia/Pontoporeia spp. populations from the northern Baltic Sea, and their potential contribution to benthic nitrogen mineralization. Mar Biol 123:555-564

Editorial responsibility: Kenneth Tenore (Contributing Editor), Solomons, Maryland, USA
Lehtonen KK (1996) Ecophysiology of the benthic amphipod Monoporeia affinis in an open-sea area of the northern Baltic Sea: seasonal variations in body composition, with bioenergetic considerations. Mar Ecol Prog Ser 143:87-98

Lehtonen KK, Andersin AB (1998) Population dynamics, response to sedimentation and role in benthic metabolism of the amphipod Monoporeia affinis in an open-sea area of the northern Baltic Sea. Mar Ecol Prog Ser 160:71-85

Lignell R, Heiskanen AS, Kuosa H, Gundersen K, Kuuppo Leinikki P, Pajuniemi R, Uitto A (1993) Fate of a phytoplankton spring bloom: sedimentation and carbon flow in the planktonic food web in the northern Baltic. Mar Ecol Prog Ser 94:239-252

Lopez G, Elmgren R (1989) Feeding depths and organic absorption for the deposit-feeding benthic amphipods Pontoporeia affinis and Pontoporeia femorata. Limnol Oceanogr 34:982-991

Lopez GR, Levinton JS (1987) Ecology of deposit-feeding animals in marine sediments. Q Rev Biol 62:119-130

Modig H, van de Bund WJ, Ólafsson E (2000) Uptake of phytodetritus by three ostracod species from the Baltic Sea: effects of amphipod disturbance and ostracod density. Mar Ecol Prog Ser 202:125-134

Moeslund L, Thamdrup B, Jørgensen BB (1994) Sulfur and iron cycling in a coastal sediment: radiotracer studies and seasonal dynamics. Biogeochemistry 27:129-152

Noji TT, Noji CIM, Barthel KG (1993) Pelagic-benthic coupling during the onset of winter in a northern Norwegian fjord. Carbon flow and fate of suspended particulate matter. Mar Ecol Prog Ser 93:1-2

Ólafsson E, Elmgren R (1991) Effects of biological disturbance by benthic amphipods Monoporeia affinis on meiobenthic community structure: a laboratory approach. Mar Ecol Prog Ser 74:99-107

Ólafsson E, Elmgren R (1997) Seasonal dynamics of sublittoral meiobenthos in relation to phytoplankton sedimentation in the Baltic Sea. Estuar Coast Shelf Sci 45:99-107

Ólafsson E, Modig H, van de Bund WJ (1999) Species specific uptake of radio-labelled phytodetritus by benthic meiofauna from the Baltic Sea. Mar Ecol Prog Ser 177:63-72

Pfannkuche O, Boetius A, Lochte $\mathrm{K}$, Lundgreen U, Thiel H (1992) Responses of deep-sea benthos to sedimentation patterns in the North-East Atlantic in 1992. Deep-Sea Res I 46:573-596

Rudnick DT (1989) Time lags between the deposition and meiobenthic assimilation of phytodetritus. Mar Ecol Prog Ser 50:231-240

Soetaert K, Herman PMJ, Middelburg JJ (1996) Dynamic response of deep-sea sediments to seasonal variations: a model. Limnol Oceanogr 41:1651-1668

Sparrevik E, Leonardsson K (1995) Effects of large Saduria entomon (Isopoda) on spatial distribution of their small S. entomon and Monoporeia affinis (Amphipoda) prey. Oecologia 101:177-184

van de Bund WJ, Goedkoop W, Johnson RK (1994) Effects of deposit-feeder activity on bacterial production and abundance in profundal lake sediment. J N Am Benthol Soc 13: 532-539

van Duyl FC, Kop AJ, Sandee AJJ (1992) The impact of organic matter and macrozoobenthos on bacterial and oxygen variables in marine sediment boxcosms. Neth J Sea Res 29:343-355

Webb DG, Montagna PA (1993) Initial burial and subsequent degradation of sedimented phytoplankton: relative impact of macro- and meiobenthos. J Exp Mar Biol Ecol 166: 151-163

Submitted: August 21, 2000; Accepted: December 6, 2000 Proofs received from author(s): February 21, 2001 